\title{
Ultrastructural description of new Rickettsia-like organisms in the commercial abalone Haliotis tuberculata (Gastropoda: Haliotidae) from the NW of Spain
}

\author{
Carlos Azevedo ${ }^{1,2, *}$, Ramón F. Conchas ${ }^{3}$, Jessica Tajdari ${ }^{2}$, Jaime Montes ${ }^{4}$ \\ ${ }^{1}$ Department of Cell Biology, Institute of Biomedical Sciences, University of Porto (ICBAS/UP), Lg. A. Salazar no. 2, \\ 4099-003 Porto, Portugal \\ ${ }^{2}$ Centre for Marine and Environmental Research, University of Porto (CIIMAR/UP), Rua dos Bragas no.177, \\ 4050-123 Porto, Portugal \\ ${ }^{3}$ Instituto Tecnolóxico para o Control do Medio Mariño de Galicia (INTECMAR), Consellería de Pesca \\ e Asuntos Marítimos, Peirao de Vilaxoán, 36611 Vilagarcia de Arousa, Spain \\ ${ }^{4}$ Centro de Investigacións Marinas (CIMA), Consellería de Pesca e Asuntos Marítimos, Pedras de Corón, \\ 36620 Villanova de Arousa, Pontevedra, Spain
}

\begin{abstract}
Rickettsia-like organisms (RLOs) were found in the commercially farmed abalone Haliotis tuberculata in the northwestern region of the Atlantic Coast of Spain and are described from light and transmission electron microscopy observations. The RLOs measured $\sim 1.6 \times 0.9 \mu \mathrm{m}$ and were found in intracytoplasmic, spherical to ellipsoidal vacuoles (up to $8 \mu \mathrm{m}$ ) in the epithelial cells of the digestive diverticulae. The morphological ultrastructure of these organisms was typically prokaryotic, including a plasmalemma and a thin Gram-negative type cell wall. Several ultrastructural changes were observed in the epithelial cells of the host containing the RLOs. The nuclei became pycnotic and several basophilic dense inclusions appeared in the cytoplasm. In addition, the host cell appeared lysed and was ruptured in advanced stages of infection. It was impossible to ascertain whether the RLOs are responsible for this disease, as a haplosporidian infection was also present. We can only conclude that the presence of RLOs simultaneously with a haplosporidian parasite may contribute to the mortality of the abalone host.
\end{abstract}

KEY WORDS: Ultrastructure $\cdot$ Rickettsia-like organisms $\cdot$ Abalone $\cdot$ Spain

\section{INTRODUCTION}

Parasitic and symbiotic species of prokaryotic microorganisms have been reported in a wide range of marine animals (Bonami \& Pappalardo 1980, Lauckner 1983, Sparks 1985, Fryer \& Lannan 1994, Wang \& Gu 2002, Nunan et al. 2003, Bower 2004). Amongst them, rickettsiae and rickettsia-like organisms (RLOs) have been reported infecting several aquatic animal groups, mainly bivalves (Harshbarger et al. 1977, Buchannan 1978, Elston 1986, Comps et al. 1987, Mialhe et al. 1987, Azevedo \& Villalba 1991, Renault \& Cochennec
1994, Gardner et al. 1995, Wu \& Pan 1999, Antonio et al. 2000, Hine \& Diggles 2002, Hine et al. 2002, Azevedo et al. 2005). These microorganisms are small, pleomorphic, rod-shaped coccoid prokaryotes, most of which are obligate intracellular Gram-positive parasites (Sparks 1985). Some RLOs have been associated with diseases and mortality in molluscs (Azevedo \& Villalba 1991, Haaker et al. 1992, Wu \& Pan 1999, Moore et al. 2000, Hine et al. 2002, Hine \& Diggles 2002). A lethal disease known as '(foot) withering syndrome', characterised mainly by atrophy of the foot muscle, has been associated with mass mortalities in 
cultured and natural populations of Haliotis spp. from different geographic areas (Antonio et al. 2000, Friedman et al. 2000, Moore et al. 2000, Bower 2004). Recently, the syndrome has been described as a severe pathogen-caused disease associated with Rickettsiales-like prokaryotes (Haaker et al. 1992, Gardner et al. 1995, Antonio et al. 2000, Moore et al. 2000, Bower 2004, Braid et al. 2005).

The purpose of this work is to document and describe the ultrastructure of RLOs found in abalone Haliotis tuberculata. These prokaryotic parasites may contribute to the mortality of this commercially important species.

\section{MATERIALS AND METHODS}

Juvenile abalone Haliotis tuberculata (Linnaeus, 1758) (Gastropoda: Haliotidae) from Ireland were grown in barrels suspended from rafts in El Grove, Galicia, NW of Spain $\left(42^{\circ} 29^{\prime} 20^{\prime \prime}\right.$ N, $08^{\circ} 53^{\prime} 56^{\prime \prime}$ W). Fifteen specimens were observed by light microscopy (LM) during a study which aimed to identify haplosporidiosis. In addition to the haplosporidian parasite, some of the specimens were also found to be parasitized by RLOs, mainly in the epithelial cells of the digestive diverticulae.

Small fragments of the parasitized tissues were fixed in $3 \%$ glutaraldehyde in $0.2 \mathrm{M}$ sodium cacodylate buffer $\mathrm{pH} 7.2$ for $10 \mathrm{~h}$ at $4^{\circ} \mathrm{C}$, washed overnight in the same buffer at $4{ }^{\circ} \mathrm{C}$, and post-fixed in buffered $2 \% \mathrm{OsO}_{4}$ for $3 \mathrm{~h}$ at $4{ }^{\circ} \mathrm{C}$. After dehydration in an ascendant ethanol series followed by propylene oxide, the tissues were embedded in Epon. Semithin sections were stained with methylene blue-Azur II and observed under differential interference contrast (DIC; Nomarski) microscopy. For transmission electron microscopy (TEM), the tissues were ultrathin-sectioned with a diamond knife, double-stained with uranyl acetate and lead citrate and observed in a JEOL 100CXII TEM operated at $60 \mathrm{kV}$.

\section{RESULTS}

Of the 10 specimens of the abalone Haliotis tuberculata parasitized by a haplosporidian identified as Haplosporidium montforti (Azevedo et al. 2006), only 6 revealed a simultaneous infection by rickettsia-like organisms (RLOs) (Fig. 1). In addition, of the 5 specimens not parasitized by the haplosporidian, 3 contained RLOs. In both cases, RLOs occurred within large intracytoplasmic vacuoles (up to $8 \mu \mathrm{m}$ in diameter) in the epithelial cells of the digestive diverticulae, where they were responsible for the formation of spherical to ellipsoidal microcolonies (Figs. 1 to 4). By observation of ultrathin transverse sections made at the level of the largest vacuoles, it was possible to count $\sim 75$ RLOs per section (Figs. $3 \& 4$ ). The total volume of the largest vacuoles was occupied by $\sim 280$ juxtaposed RLO cells.

The RLOs were polygonal in shape, and packed into vacuoles with no intercellular spaces. The chromatin was organized into several compacted and irregular patches (Figs. $3 \& 4$ ). Infected cells were hypertrophied and the cytoplasm was largely replaced by the developing RLO microcolony (Figs. 2 to 4). In favourable longitudinal sections it was possible to observe that the RLO vacuoles occupied a basal position beneath the nuclei of the epithelial cells (Fig. 4). The histopathological changes caused by the presence of RLOs in the epithelial cells of the digestive diverticulae included an increase in the volume of the vacuole and substantial ultrastructural alterations of the nucleus that became pycnotic. Additionally, several vacuoles and dense bodies appeared in the cytoplasm of the host cells (Figs. 3 \& 4). The most evident alterations were observed at the apical periphery of the host cells where the luminar microvilli disappeared (Fig. 4). Sometimes disrupted vacuoles and free RLOs were observed among host tissues where the cell appeared lysed and the epithelial tissues of the host were disrupted (Fig. 1).

Figs. 1 to 4. One photo- and 3 electronmicrographs of the rickettsia-like organisms (RLOs) found in the abalone Haliotis tuberculata. Fig. 1. Semithin section of ephitelial cells of the digestive diverticulae showing intracytoplasmic vacuoles (arrows) containing RLOs near the nuclei (N) of the host cells. Some of the host cells are disrupted (*). Internally, several haplosporidian spores can be observed. Fig. 2. Ultrastructural aspect of 2 intracytoplasmic vacuoles containing RLOs (arrows) projected towards the lumen of the digestive diverticulae epithelial cells, where numerous microvilli (Mv) are present. In the cytoplasm of these cells some vacuoles $(*)$ and dense basophilic bodies (arrowheads) are observed. Fig. 3. Ultrastructural aspects of epithelial cells containing an intracytoplasmic vacuole with RLOs (arrows). The nuclei (N) are irregularly shaped and seem to be pycnotic. Several dense basophilic bodies (arrowheads) are present in the cytoplasm. Fig. 4. Ultrastructural aspect of the longitudinal section of 2 epithelial cells, each containing a nucleus $(\mathrm{N})$ and an elongated intracytoplasmic vacuole with RLOs (arrows). At the apical region of the cell (*), the microvilli of the epithelial host cells have disappeared. The basal region is occupied by numerous dense basophilic bodies (arrowheads) 


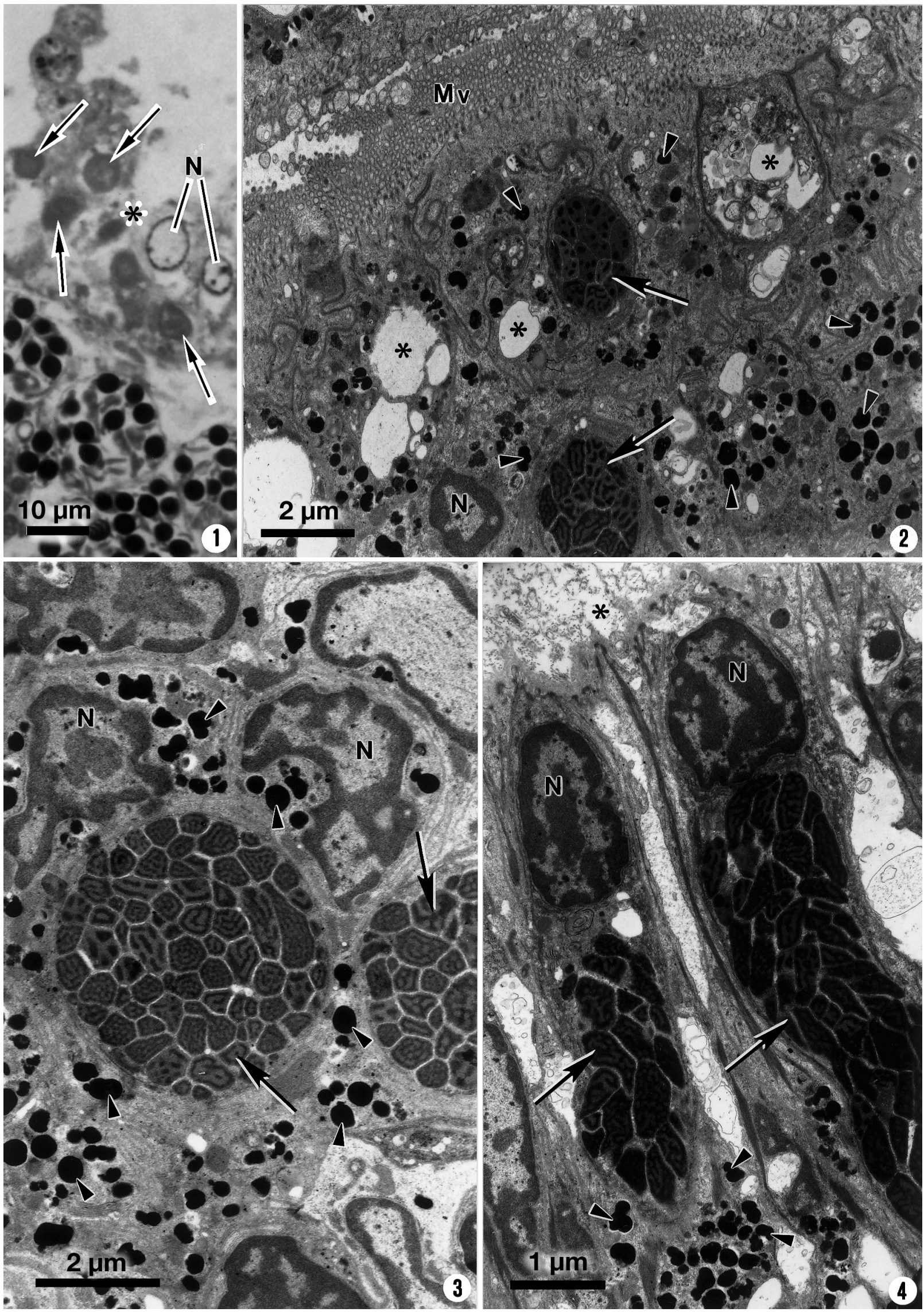




\section{DISCUSSION}

The ultrastructural morphology of the prokaryotic microorganisms reported here is similar to that of other RLOs previously described in several species of aquatic fauna (Lauckner 1983, Sparks 1985, Gardner et al. 1995). RLOs differ from bacteria because they lack a true bacterial wall (Elston 1986, Azevedo \& Villalba 1991, Bower 2004). These prokaryotes have been reported from marine animals (Lauckner 1983), mainly crustaceans (Bonami \& Pappalardo 1980, Fryer \& Lannan 1994, Nunan et al. 2003) and bivalves (Buchannan 1978, Elston 1986, Azevedo \& Villalba 1991, Gardner et al. 1995, Hine \& Diggles 2002, Hine et al. 2002, Azevedo et al. 2005). Previous studies on bivalves infected with rickettsia or RLOs have demonstrated that these prokaryotes can cause important losses in commercially farmed bivalves (Gardner et al. 1995, Friedman et al. 2000, Hine et al. 2002, Bower 2004).

The ultrastructural organization of the compacted chromatin of the RLOs studied in the present work differs from all the other rickettsia and RLOs previously described in molluscs (Elston 1986, Comps et al. 1987, Azevedo \& Villalba 1991, Gardner et al. 1995, Azevedo et al. 2005).

The RLOs described in the present paper were found coincidentally in tissues of cultured Haliotis tuberculata which had experienced high mortality possibly due to the presence of a haplosporidian infection identified as Haplosporidium montforti (Azevedo et al. 2006). During an ultrastructural study of a recently identified haplosporidian found among cultured abalone Haliotis iris, rickettsiae were also encountered and associated with the mortality of the host (Hine et al. 2002). In addition, epizootic mortalities associated with amyotrophia have been observed in hatcheries of the Japanese black abalone Nordotis discus discus (Otsu \& Sasaki 1997, Nakatsugawa et al. 2000). The appearance of RLOs in the same hosts where a high mortality was associated with the infection of $H$. montforti may indicate that RLOs contribute to mortality of the abalone. Moribund and dead abalones contained these 2 types of infections simultaneously. The mortality that occurred in the abalone $H$. tuberculata could not be attributed to the RLO infection alone, because of the presence of another pathogen (H. montforti) (Azevedo et al. 2006) in the same samples. In spite of the fact that the abalones showed symptoms corresponding to those caused by 'withering syndrome', it was not possible to establish a definitive connection between the presence of the RLOs and the disease, because of the haplosporidian co-infection.

Acknowledgements. We thank Mr. J. Carvalheiro for the micrographic work (ICBAS/UP). This work was partially supported by the Eng. Antonio de Almeida Foundation (Porto, Portugal).

\section{LITERATURE CITED}

Antonio DB, Andree KB, Moore JD, Friedman CS, Hedrick RP (2000) Detection of Rickettsiales-like prokaryotes (RLPs) by in situ hybridization in black abalone Haliotis cracherodii with Withering Syndrome. J Invertebr Pathol $75: 180-182$

Azevedo C, Villalba A (1991) Extracellular giant Rickettsia associated with bacteria in the gill of Crassostrea gigas (Mollusca, Bivalvia). J Invertebr Pathol 58:75-81

Azevedo C, Mendonça I, Matos E (2005) Ultrastructural analysis of Rickettsia-like organisms in the oyster Crassostrea rizophorae from the Northeastern Atlantic coast of Brazil. Braz J Morphol Sci 22:5-8

Azevedo C, Balseiro P, Casal G, Gestal C (2006) Ultrastructural and molecular characterization of Haplosporidium montforti n. sp., parasite of the European abalone Haliotis tuberculata. J Invertebr Pathol 92:23-32

Bonami JR, Pappalardo R (1980) Rickettsial infection in marine Crustacea. Experientia 36:180-181

Bower SM (2004) Synopsis of infectious diseases and parasites of commercially exploited shellfish. Available at: http://www-sci.pac.dfo-mpo.gc.ca/shelldis/pages/fwsab_e. htm

Braid BA, Moore JD, Robbins TT, Hedrick RP, Tjeerdema RS, Friedman CS (2005) Health and survival of red abalone, Haliotis rufescens, under varying temperature, food supply, and exposure to the agent of withering syndrome. J Invertebr Pathol 89:219-231

Buchannan JS (1978) Cytological studies on a new species of rickettsia in association with a phage in the digestive gland of the marine bivalve mollusc, Tellina tenuis (da Costa). J Fish Dis 1:27-43

Comps M, Ruano F, Grizel H (1987) An infection of Ruditapus dicussatus (Bivalvia) by Rickettsia. Aquaculture 67: $258-259$

Elston R (1986) Occurrence of branchial rickettsia-like infections in two molluscs, Tapes japonica and Patinocteu yessoensis with comments on their significance. J Fish Dis 9:69-71

Friedman CS, Robbins TT, Moore JD, Shields JD, Andree KB, Beauchamp KA, Antonio DB, Hedrick RP (2000) 'Candidatus Xenohaliotis californiensis', a newly described bacterial pathogen and etiological agent of abalone withering syndrome. (Abstract). J Shellfish Res 19:645

Fryer JL, Lannan CN (1994) Rickettsial and chlamydial infections of freshwater and marine fishes, bivalves and crustaceans. Zool Stud 33:95-107

Gardner GR, Harshbarger JC, Lake JL, Sawyer TK, Price KL, Stephenson MD, Haaker PL, Togstad HA (1995) Association of prokaryotes with symptomatic appearance of withering syndrome in black abalone Haliotis cracherodii. J Invertebr Pathol 66:111-120

Haaker PL, Parker DO, Togstad H, Richards DV, Davis GE, Friedman CS (1992) Mass mortality with withering syndrome in black abalone Haliotis cracherodii, in California. In: Shepard SA, Tegner MJ, Guzman del Proo SA (eds) Abalone of the world. Blackwell Scientific, Oxford, p 214-224

Harshbarger JC, Chang SC, Otto SV (1977) Chlamydiae (with phages), mycoplasmas, and rickettsiae in Chesapeake Bay Bivalves. Science 196:666-668

Hine PM, Diggles BK (2002) Prokaryote infections in the New Zealand scallops Pecten novaezelandiae and Chlamys delicatula. Dis Aquat Org 50:137-144

Hine PM, Wakefield S, Digghs VL, Maas EW (2002) Ultrastructure of a haplosporidian containing rickettsiae, asso- 
ciated with mortalities among cultured paua Halotis iris. Dis Aquat Org 49:207-219

Lauckner G (1983) Diseases of Mollusca: Bivalvia. In: Kinne O (ed) Diseases of marine animals, Vol 2. Biologische Anstalt Helgoland, Hamburg, p 447-520

Mialhe E, Chagot D, Boulo V, Comps M, Ruano F, Grizel H (1987) An infection of Ruditapes decussatus (Bivalvia) by Rickettsia. Aquaculture 67:258-259

Moore JD, Robbins TT, Friedman CS (2000) Withering syndrome in farmed red abalone Haliotis rufescens: Thermal induction and association with a gastrointestinal rickettsia-like prokaryote. J Aquat Anim Health 12:26-34

Nakatsugawa T, Okabe M, Muroga K (2000) Horizontal transmission of amyotrophia in Japanese black abalone. Fish Pathol 35:11-14

Nunan LM, Poulos B, Redman R, LE Grumellec M, Lightner DV (2003) Molecular detection methods developed for a systemic rickettsia-like bacterium (RLB) in Penaeus mon-

Editorial responsibility: Albert K. Sparks, Seattle, Washington, USA odon (Decapoda: Crustacea). Dis Aquat Org 53:15-23

Renault T, Cochennec N (1994) Rickettsia-like organisms in the cytoplasm of gill epithelial cells of the Pacific oyster Crassostrea gigas. J Invertebr Pathol 64:160-162

Otsu R, Sasaki K (1997) Virus-like particles detected from juvenile abalones (Nordotis discus discus) reared with an epizootic fatal wasting disease. J Invertebr Pathol 70: $167-168$

Sparks AK (1985) Rickettsia, clamydiae and mycoplasmas of invertebrates. In: Sparks AK (eds) Synopsis of invertebrate pathology. Elsevier, Amsterdam, p 165-180

Wang W, Gu Z (2002) Rickettsia-like organism associated with tremor disease and mortality of the Chinese mitten crab Eriocheir sinensis. Dis Aquat Org 48:149-153

Wu X, Pan J (1999) Studies on rickettsia-like organism disease of the tropical marine pearl oyster. 1: The fine structure and morphogenesis of Pinctada maxima pathogen rickettsia-like organism. J Invertebr Pathol 73:162-172

Submitted: December 17, 2005; Accepted: May 14, 2006

Proofs received from author(s): July 26, 2006 